\title{
OVER THE TOP: IMPACTS ON THE NETWORKS OF SMALL INTERNET ACCESS PROVIDERS
}

\section{ORIGINAL ARTICLE}

SILVA, Antônio Eugênio ${ }^{1}$

SILVA, Antônio Eugênio. Over The Top: Impacts on the networks of small internet access providers. Revista Científica Multidisciplinar Núcleo do Conhecimento. 04 year, Ed. 09, Vol. 02, pp. 05-23. September 2019. ISSN: 2448-0959, Access link in: https://www.nucleodoconhecimento.com.br/science-of-music/networks-of-small-

\section{internet}

\section{SUMMARY}

The Internet represents a transformative force of paradigms, making everyday situations such as how to watch movies and interact with society have a rapid transformation in recent years, driven by the distribution platforms of online video over the Internet, which consist of cross-platform distributed systems forming the so-called over the top - OTT. Sending video content on the Internet requires a variety of infrastructure devices associated with the Internet Service Provider - ISP, which must provide sufficient bandwidth Internet access to ensure quality of service. The growth in broadband Internet use raises concerns for ISPs due to the high bandwidth demands generated by OTT applications. The characterization of users' behavior for OTT services can contribute to a better understanding of the interaction of users of these services with ISP, which will help small ISPs manage the capacity of their resources by providing a better quality of the service provided and possibilities for offering new

$1 \mathrm{PhD}$ in The Treatment of Spatial Information; Master's degree in Electrical Engineering; Specialization in Business MBA - Business Management; Specialization in Information Engineering; Specialization in Data Communication Engineering; Specialization in Electrical Engineering; Graduation in Electrical Engineering. 
services. This work aims to evaluate, using a case study, the impacts of OTT services, specifically Netflix, Facebook and Google, on a small broadband Internet access provider. In the research, real data were monitored and collected from all clients of an ISP using the PRTG, Winbox, Wireshark, and legacy applications tools on edge routers. With the result of the case study one can have a reference for the dimensioning of internet backbone access links with the use of CDN in the ISP environment, because users' traffic in access to OTT services in small ISP affects on average $52 \%$ of the tráfeg the total ISP.

Keywords: OTT, CDN, internet, internet provider.

\section{INTRODUCTION}

The Internet represents a transformative force of paradigms, making everyday situations such as how to watch movies and interact with society have a rapid transformation. As an example, television shows are structured in programming grids defined and displayed at certain times, while online video distribution platforms over the Internet, such as youtube and Netflix, deliver content through the choice of the user, interactively and in various technological devices.

Online video distribution platforms over the Internet consist of cross-platform distributed systems forming the so-called over the top - OTT. They are online services that replace traditional media and telecommunications services. It consists of a multimedia service that travels through a third-party network, in which the OTT service provider has no responsibility for the means of access to the service provided. The term OTT is used for services that have their own servers for internet distribution, some examples are: IP TV; IP radio; instant messaging, audiovisual connections; video on demand - VOD; among others. In this context is at the origin of the term OTT, in which you can navigate a site in the same way as a computer. Several devices connect without the need to be technologically similar. Examples of OTT services are shown in Figure 1. 
Figure 1 - Types of OTT services

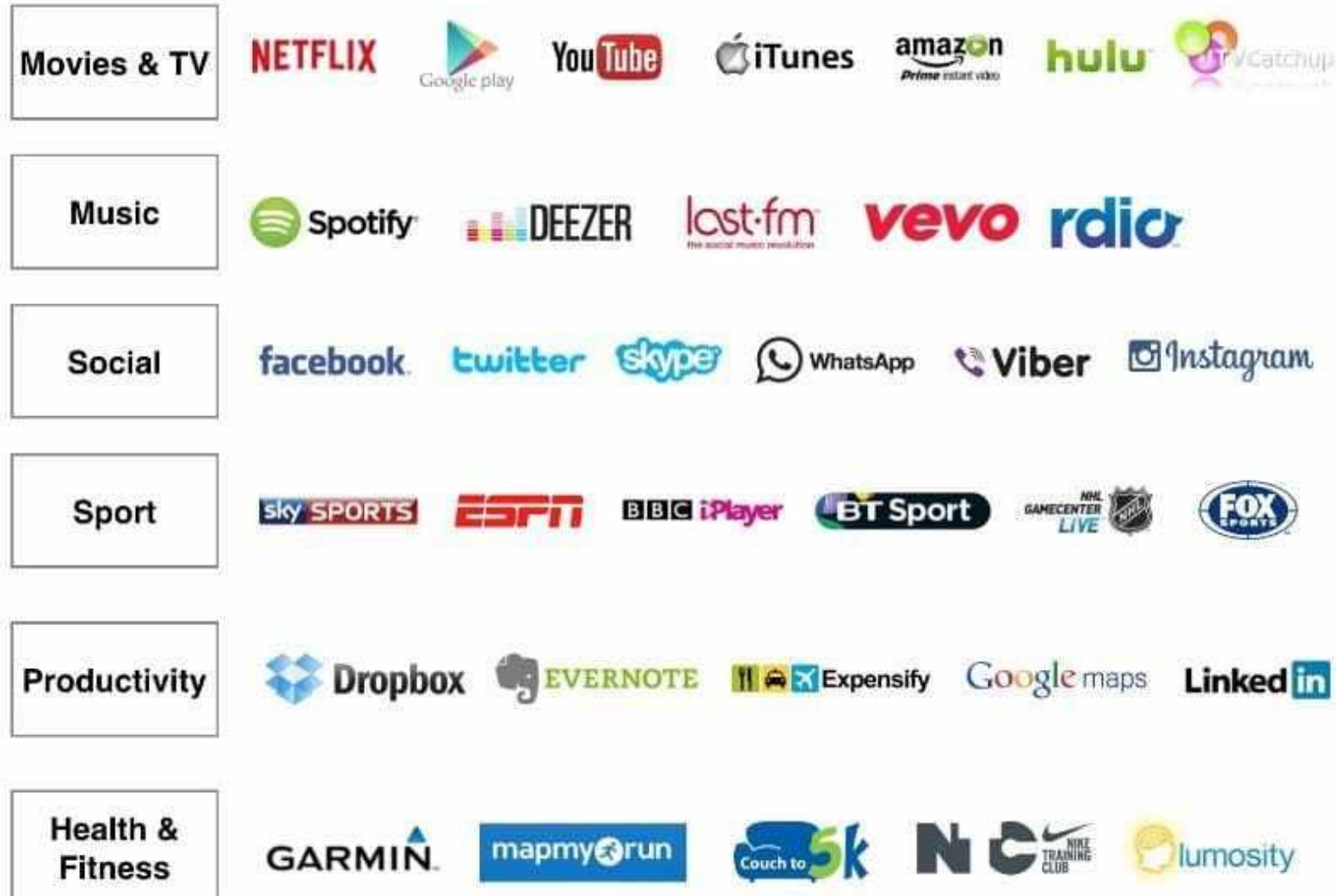

Source: OTT SOURCE, 2013

The distribution procedure, on an OTT platform, is called streaming and has several forms of shipping depending on the need of each user. For streaming to occur, you must follow an architecture. There are layers in it that influence each time of submission due to the procedures that are followed. For each type of submission, a pattern is processed, depending on criteria such as the type of transmission, quality of service, sending protocols, servers that store the media, and finally which devices will receive and which applications will receive transmit the content.

Due to the lack of multicast deployment on the Internet, large-scale OTT content distribution is a major challenge. Several forms have been used to make it possible to 
distribute large-scale live multimedia, such as adaptive streaming, the use of peer-topeer networks (P2P) and content delivery network (CDN).

Sending video content on the Internet requires a variety of infrastructure devices associated with Internet Service Providers (ISP) internet service providers, which have to make internet access binding available with bandwidth sufficient to ensure the quality of the service. High access availability and data transmission speed, which can range from 256 Kbps (Cable or Digital Subscriber Line - DSL) up to 1 Gbps in Fiber To The Home - FTTH, are important features of broadband Internet that influence the behavior of users.

The advancement of the adoption of Information and Telecommunications Technologies - ICT is directly related to the development and expansion of infrastructure and the provision of Internet access provided by ISPS. In relation to the market served by providers, most ISPs offer their services to the private market (90\%) and home (88\%). Small providers, with less than 50,000 accesses, play a key role, because they primarily serve the home market (91\%, compared to $75 \%$ of mediumsized ISP companies and $51 \%$ of large ISP companies). As intermediaries that enable Internet access, providers provide the platform for communication technologies, playing a very relevant role for the development of the Internet in the country $(\mathrm{CGI}$, 2016).

Thus, the growth in broadband Internet use, led by increased traffic generated by OTT operators, raises concerns for ISPs, as many of the applications impose a workload characterized by long-term sessions with traffic of data (KURBALIJA, 2016).

According to Sandvine, 2016, in its report "Global Internet Phenomena" in 2016, audio and video streaming accounted for $71 \%$ of night traffic on North American fixed-access networks. Sandvine expects this number to reach $80 \%$ by 2020 . The addition of video and voice calls is generating growth in mobile communication applications in Latin America and North America. In Latin America, WhatsApp's share of traffic is now $7.4 \%$, more than triple than it was two years ago. In Latin America, Facebook and Google 
account for more than $70 \%$ of total mobile traffic in the region - $60 \%$ last year. More than $60 \%$ of mobile traffic in Latin America and North America is encrypted. Figure 2 shows the 10 applications with the highest Internet traffic in Latin America in 2016.

Figure 2 - Percentage of use per application of total Internet traffic

\begin{tabular}{|l|r|l|r|l|r|}
\hline \multicolumn{2}{|c|}{ Upstream } & \multicolumn{2}{c|}{ Downstream } & \multicolumn{2}{c|}{ Aggregate } \\
\hline BitTorrent & $30.03 \%$ & YouTube & $28.48 \%$ & YouTube & $25.91 \%$ \\
\hline YouTube & $9.30 \%$ & HTTP - OTHER & $11.66 \%$ & HTTP - OTHER & $11.12 \%$ \\
\hline HTTP - OTHER & $7.59 \%$ & SSL - OTHER & $9.76 \%$ & BitTorrent & $10.06 \%$ \\
\hline Facebook & $6.72 \%$ & Netflix & $8.31 \%$ & SSL - OTHER & $9.28 \%$ \\
\hline SSL - OTHER & $6.19 \%$ & BitTorrent & $6.96 \%$ & Netflix & $7.45 \%$ \\
\hline Ares & $5.27 \%$ & Facebook & $5.10 \%$ & Facebook & $5.32 \%$ \\
\hline Skype & $2.53 \%$ & MPEG - OTHER & $2.28 \%$ & MPEG - OTHER & $2.10 \%$ \\
\hline Netflix & $1.97 \%$ & RTMP & $1.79 \%$ & RTMP & $1.66 \%$ \\
\hline Dropbox & $1.16 \%$ & Google Market & $1.69 \%$ & Google Market & $1.52 \%$ \\
\hline MPEG - OTHER & $0.92 \%$ & Flash Video & $1.60 \%$ & Flash Video & $1.46 \%$ \\
\hline & $71.69 \%$ & & $77.63 \%$ & & $75.87 \%$ \\
\hline
\end{tabular}

sandvine

Source: Sandvine, 2016

In Brazil, video traffic on the Internet will grow 3-fold between 2016 and 2021, a composite annual growth rate of $23 \%$. Internet video traffic will reach 4.0 Exabytes per month in 2021, up from 1.4 Exabytes per month in 2016. Total video traffic on the Internet (commercial and domestic combined) will be $84 \%$ of all Internet traffic in 2021 , up from $68 \%$ in 2016. Domestic consumer video traffic on the Internet will be $86 \%$ of total consumer-generated traffic in 2021, up from 72\% in 2016 (CISCO, 2017).

In this context, ISP and telecommunications operators advance in the provision of OTT services as a complement to the pay TV offering. In addition to ensuring a good user experience using solutions that increase delivery speed, such as CDN, which basically saves static content to a location closer to the user and, in some cases, can set a better path to the data network using connections to the Traffic Exchange Point - PTT. PTT is a network solution with the objective of enabling direct connection between the entities that make up the Internet, the Autonomous Systems (AS). It is a shared

Disponível em: https://www.nucleodoconhecimento.com.br/science-of-music/networks-of-smallinternet 
infrastructure that is installed in a region to receive as connections called peering, wit $h$ the aim of improving Internet performance by maintaining the most localized traffic exchange between different networks by decreasing the number of jumps between the AS. Once connected to the PTT, its members may agree to peering with multilateral traffic exchange (ATM) with all other members openly or peering wit $h$ bilateral traffic agreements (ATB) of a selective or restrictive nature.

Therefore, ISPs need to improve the use of their resources to comply with service level agreement (SLA) agreements established with their clients and required by regulatory agency ANATEL, mainly respecting the civil framework of the Internet in the net neutrality issue, which does not allow ISP to give priority of traffic to certain sites or applications to the detriment of others (NETO et al, 2007). ISPs need to constantly know and monitor the demand of their users to define their infrastructure, such as scaling internet backbone access links via Internet Protocol (IP) port and/or using PTT and/or connections use of CDN in the ISP environment or via PTT. This aims to reduce costs, recover investments and, mainly, contribute to the insertion of the Brazilian population in the Information Society or in the Network Society, as defined by Castells (1999).

\subsection{JUSTIFICATION}

OTT platforms have modified and driven internet traffic. Services like Netflix have changed the face of American TV. Also, the company has revolutionized data consumption in the United States - USA. According to a 2016 study by Sandvine, the service occupied $37 \%$ of Internet data traffic in the country in 2015 . Just behind, another video platform: YouTube, with $18 \%$. The study shows that $61 \%$ of all U.S. data traffic in 2015 is video services. The data is enhanced by users who abandoned pay TV and migrated to streaming, in a phenomenon called "cord-cutter" (cut the cable, in free translation), which gives name to a type of user who stops paying for pay TV to watch videos only (SANDVINE, 2016). 
According to Cisco (2017) in the Visual Networking Index (VNI), released in June 2017, globally, IP video traffic will be $82 \%$ of all consumer Internet traffic in 2021, up from $73 \%$ in 2016 and $75 \%$ in 2017. Global IP video traffic will grow three times from 2016 to 2021 . Live videos on the Internet will account for $17 \%$ of Internet video traffic by 2022. Live video will grow 15 times from 2017 to 2022. Content delivery networks (CDNs) will carry $72 \%$ of Internet traffic by 2022, compared to $56 \%$ in 2017 (CISCO, 2018).

Another international body that tracks ott's impacts on the world is the International Telecommunications Union (ITU-T). The economic impact of OTT services is a study area covered by Question 9/3 of the ITU-T 3 Study Group.

In Brazil, there are no definitive studies that measure the impact of OTT platforms, especially on small providers, although the situation is expected to be no different from that observed in the U.S. and Latin America. According to estimates by the Information and Coordination Center of Point BR (NIC.br), services such as YouTube, Netflix, Facebook and Google generate up to $60 \%$ of the traffic of residential users in the country.

Thus, it is important and necessary to know and monitor the demand of users' OTT services so that small ISP can define the best way to meet these current demands. ISPs need to avoid overloading their networks at times of high access demand and recover spending and investments from the improvement in the use of their resources, especially in the way ott services are available. The characterization of users' behavior for OTT services can contribute to a better understanding of the interaction of users of these services with ISPs, allowing small ISPs to manage the capacity of their resources, offer new services with better quality and maintain their customer base, as customers who receive a better experience from OTT services are less likely to change the broadband provider (OVUM, 2016).

One of the motivations for the study of ott impacts on the small providersector is to contribute relevant information to the dissemination of quality Internet access and to 
the development of policies that benefit the Brazilian population as a whole in the their insertion in the Information Society, because small ISPs are directly responsible for the care of the home market in Brazil, especially in regions not assisted by large operators.

\subsection{MATERIALS AND METHODS}

During the case study, data traffic from 8000 to 10,000 users of a broadband Internet provider via fiber optic scan of the city of Montes Claros/MG were monitored, collected and analyzed from November 2017 to April 2019. These users correspond to all existing broadband subscribers at the start and end of the search.

The analyzed data were collected at intervals of 60 minutes, for at least one week, in order to allow monitoring seasonalities in Internet use within seven days before and after the deployment of cdn from Netflix, Facebook and Google. At first, these samples are statically sufficient, since it can be inferred that the use of band by customers is generally constant in their daily lives.

Netflix, Facebook and Google CDs were deployed on 11/20/2017, 13/08/2018 and 10/10/2018. The capabilities of internal links to connections to Netflix, Facebook, and Google servers are respectively, 20 Gbps, $20 \mathrm{Gbps}$, and $15 \mathrm{Gbps}$ respectively.

The Paessler Router Traffic Grapher (PRTG) network monitoring system (PRTG), which uses the SNMP protocol, and legacy applications on edge routers was used.

The two edge routers have, respectively, capacity of $4 \mathrm{Gbps}$ and $1.5 \mathrm{Gbps}$, totaling 5.5 Gbps in both Internet access links. No conditioning or contention is implemented in the traffic generated by subscribers in the ISP. 


\section{RESULTS}

\subsection{SUBSCRIBER TRAFFIC BEFORE AND AFTER NETFLIX CDN ACTIVATION}

The Netflix CDN was deployed to the provider on November 20, 2017. The speeds of Internet access plans offered to customers were $20 \mathrm{Mbps}, 50 \mathrm{Mbps}$ and $100 \mathrm{Mbps}$, with a higher predominance of the $20 \mathrm{Mbps}$ plan.

It is observed in Figure 3 that after that date there was an average reduction in downstream traffic close to 600 Mbps and upstream remained unchanged. Downstream traffic corresponds to the inbound traffic marked in the legend of Figure 3. And upstream to outbound traffic.

Because average downstream traffic prior to the Netflix CDN deployment was close to 3 Gbps, it can be inferred that netflix's average traffic accounted for approximately $20 \%$ (twenty percent) of total downstream traffic and 17.1 percent of the provider's total traffic.

Figure 3 - Total traffic before and after netflix CDN deployment

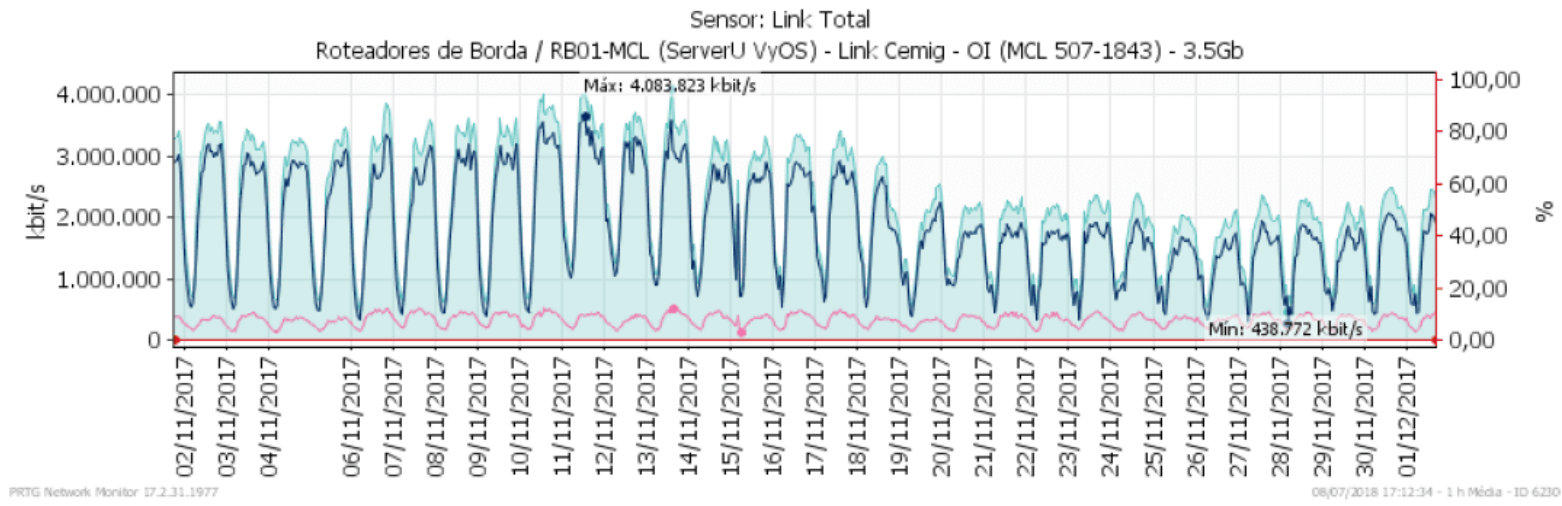

Tempo de inativid...(\%) \Tráfego total (kbit/s) $\square$ Tráfego de en... (kbit/s) \Tráfego de saí... (kbit/s)

Source: Search data

Disponível em: https://www.nucleodoconhecimento.com.br/science-of-music/networks-of-smallinternet 
Figure 4 shows specific Netflix traffic on other dates. In the caption inbound traffic represents the use of customers, that is, the downstream speed of customers. And outbound traffic represents the speed used by Netflix to update your servers, which on average is below $600 \mathrm{Mbps}$ and is performed in periods outside the increased use of provider Internet users.

Figure 4 - Netflix specific traffic in other periods

Netflix

Capacidade: 20Gbps / Download Máximo no período: 1,1 Gbps

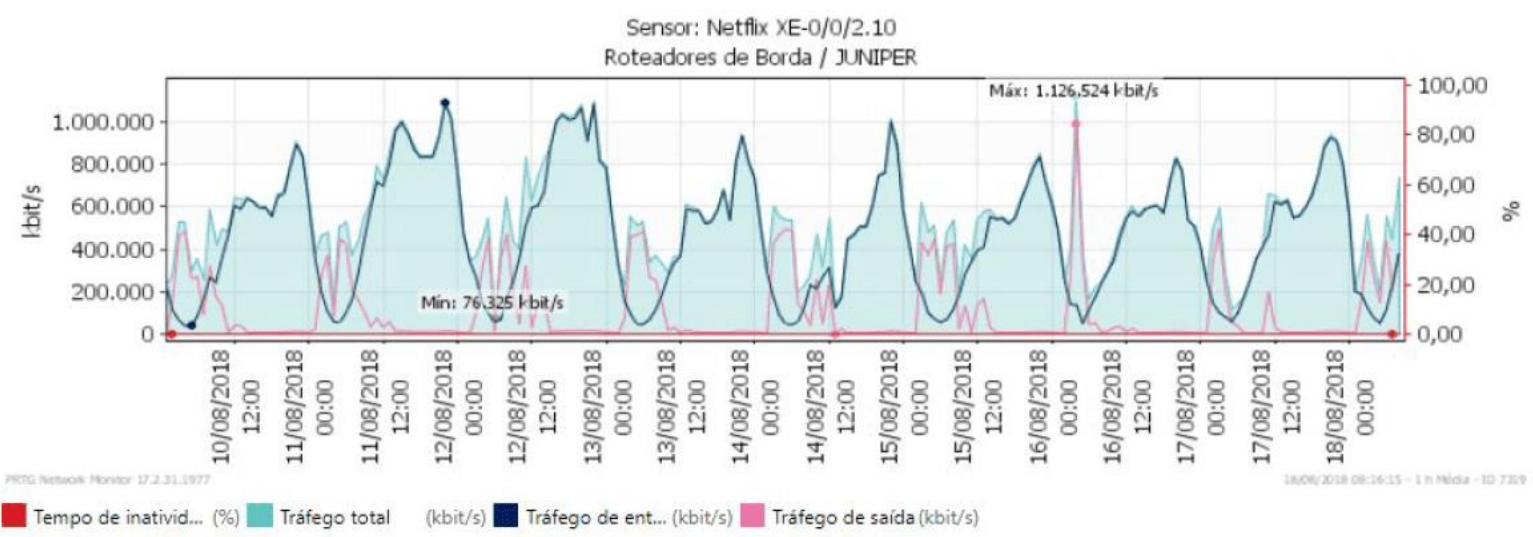

Source: Search data

Netflix

Capacidade: 20Gbps / Download Máximo no período: 1,16 Gbps

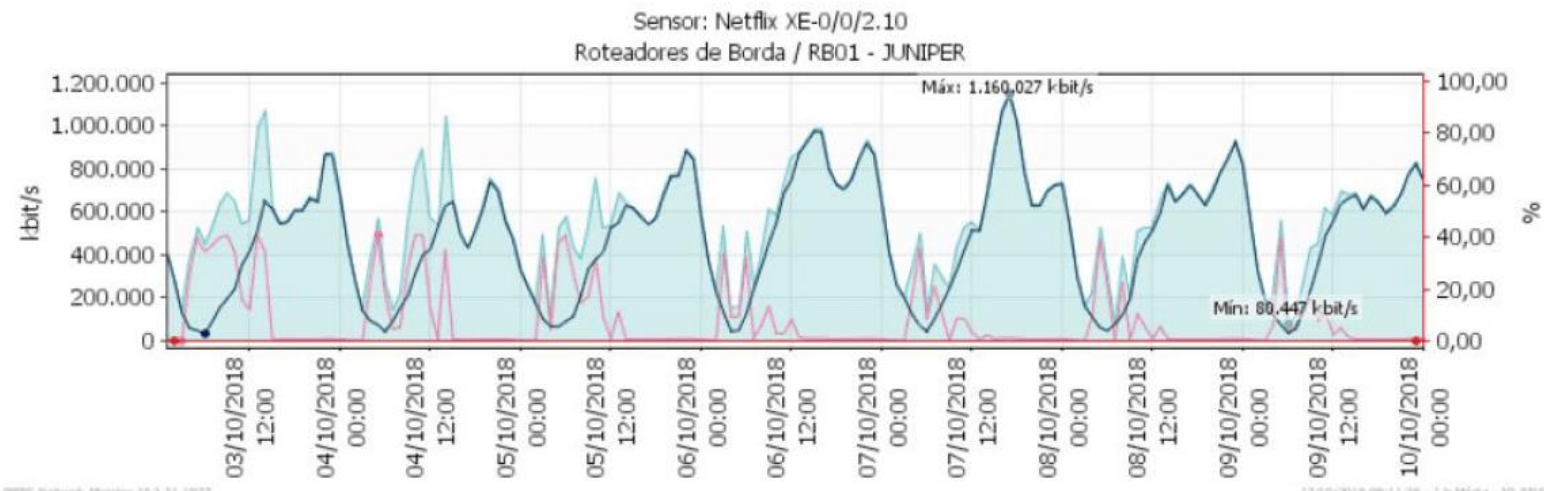

Tempo de inativid... (\%) I Tráfego total (kbit/s)

Source: Search data

RC: 39487

Disponível em: https://www.nucleodoconhecimento.com.br/science-of-music/networks-of-smallinternet 


\subsection{SUBSCRIBER TRAFFIC BEFORE AND AFTER ACTIVATION OF CDN FACEBOOK}

Facebook CDN was deployed to the provider on August 13, 2018, meaning after the netflix CDN was activated.

Figure 5 shows that in the period prior to activation, the maximum total dowload in bot $h$ links was $3.95 \mathrm{Gbps}$. In this period the provider's total customers were close to 9,000 (nine thousand) customers. The speeds of Internet access plans offered to customers were $50 \mathrm{Mbps}, 100 \mathrm{Mbps}$ and $120 \mathrm{Mbps}$, with a higher prevalence of the $50 \mathrm{Mbps}$ plan.

Figure 5 - Total traffic on both links before and after activation of CDN Facebook
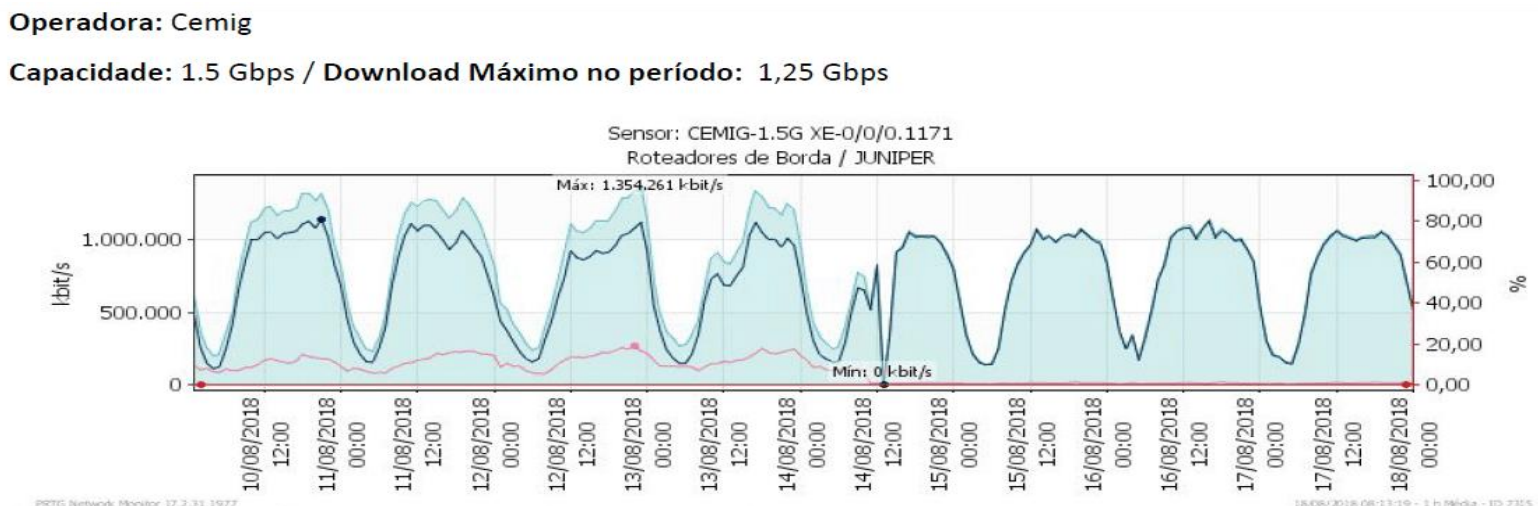

Tempo de inativid... (\%) Tráfego total (kbit/s) Tráfego de ent... (kbit/s) Tráfego de saída (kbit/s)

Source: Search data

Operadora: 01

Capacidade: 4Gbps / Download Máximo no período: 2,7 Gbps

Sensor: Link Total Roteadores de Borda / RB01-MCL (ServerU VyOS) - Link: OI (MCL 507-1843) - 3.5Gb

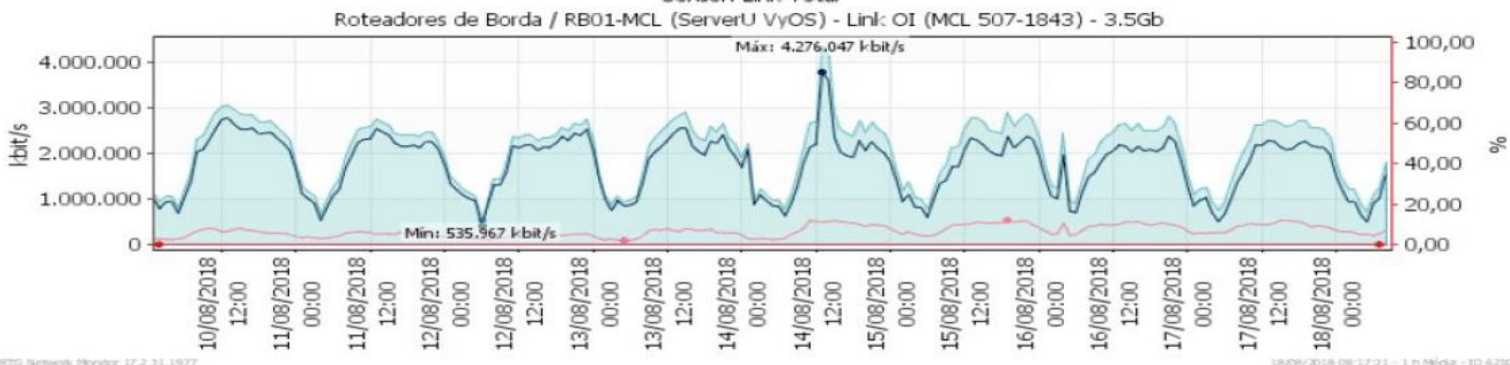

Tempo de inativid... (\%) Tráfego total (kbit/s) Tráfego de ent... (kbit/s) Tráfego de saida (kbit/s)

Source: Search data

RC: 39487

Disponível em: https://www.nucleodoconhecimento.com.br/science-of-music/networks-of-smallinternet 
Figure 6 shows total traffic from cdn Facebook. It is observed that the average traffic of this $\mathrm{CDN}$ remained close to $600 \mathrm{Mbps}$. Considering the maximum downstream traffic of the two $3.95 \mathrm{Gbps}$ links, it can be inferred that average CDN Facebook traffic accounted for 15.2 percent (fifteen, two percent) of the provider's total downstream traffic. Facebook upstream traffic accounts for an average of $50 \%$ of downstream traffic.

Figure 6 - FACEBOOK CDN Traffic

\section{Facebook}

Capacidade: 20Gbps / Download Máximo no período: 650 Mbps

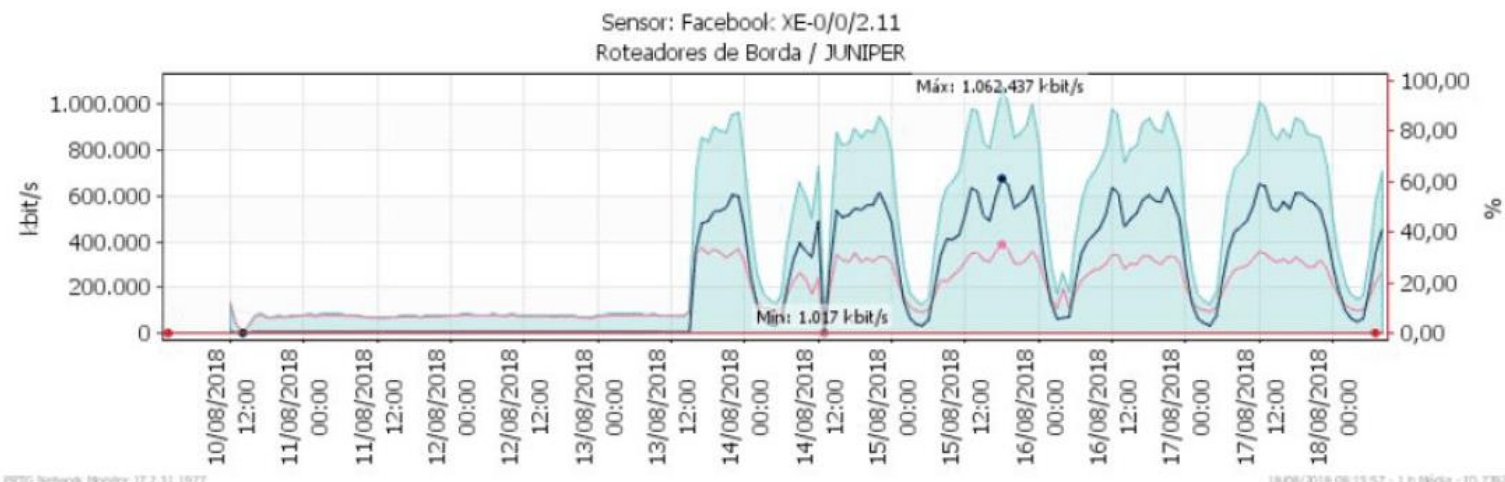

Tempo de inativid... (\%) Tráfego total (kbit/s)

Tráfego de ent... (kbit/s) $\square$ Tráfego de saida (kbit/s)

Source: Search data

Facebook

Capacidade: 20 Gbps / Download Máximo no período: 790 Mbps

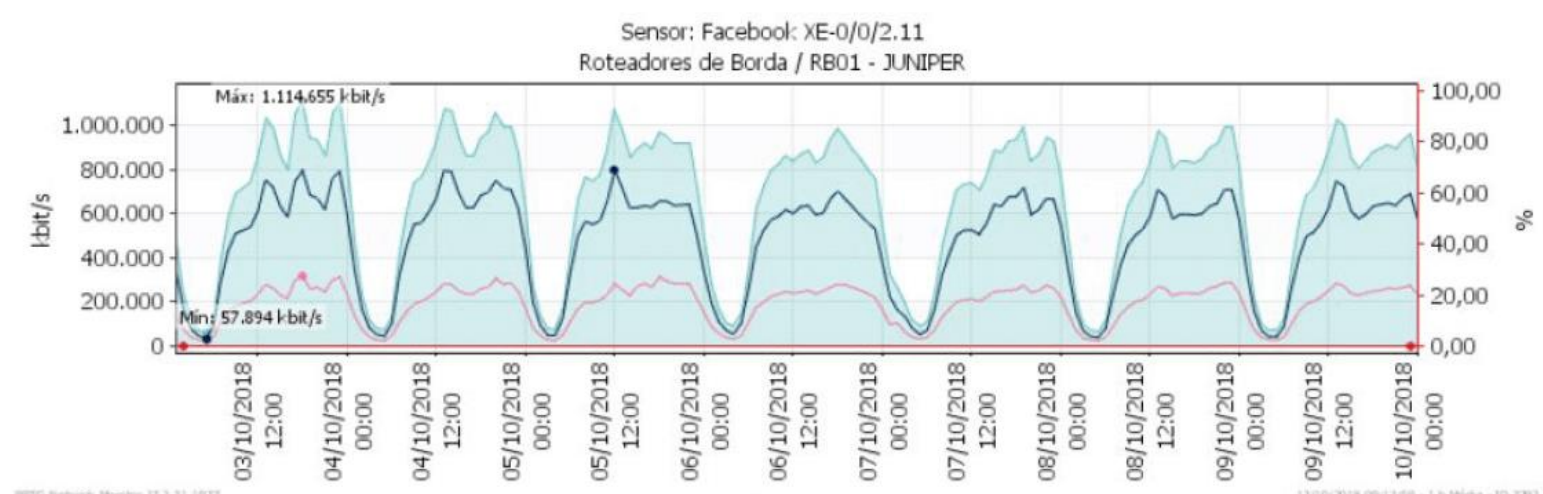

Tempo de inativid... (\%) \ Tráfego total (kbit/s)

Tráfego de ent... (kbit/s) Tráfego de saida (kbit/s)

Source: Search data

RC: 39487

Disponível em: https://www.nucleodoconhecimento.com.br/science-of-music/networks-of-smallinternet 


\subsection{SUBSCRIBER TRAFFIC BEFORE AND AFTER ACTIVATION OF GOOGLE CDN (INCLUDING YOUTUBE)}

Google's CDN was deployed to the provider on October 11, 2018, that is, after the deployments of Netflix and Facebook CDNs. In this period the provider's total customers were close to 9,200 (nine thousand and two hundred) customers. The speeds of Internet access plans offered to customers were $50 \mathrm{Mbps}, 100 \mathrm{Mbps}$ and 120 Mbps, with a higher prevalence of the 50 Mbps plan.

Figure 7 is represented with the total traffic of the two links of the provider. Considering maximum downstream traffic on both 3.66 Gbps links and Google's maximum downstream of $660 \mathrm{Mbps}$ (see Figure 8), it can be inferred that the maximum traffic of the Google CDN represented $18 \%$ (eighteen percent) of the provider's total downstream traffic.

Figure 7 - Total traffic on both links before and after google CDN activation

Operadora: Cemig

Capacidade: 1.5 Gbps / Download Máximo no período: 861 Mbps

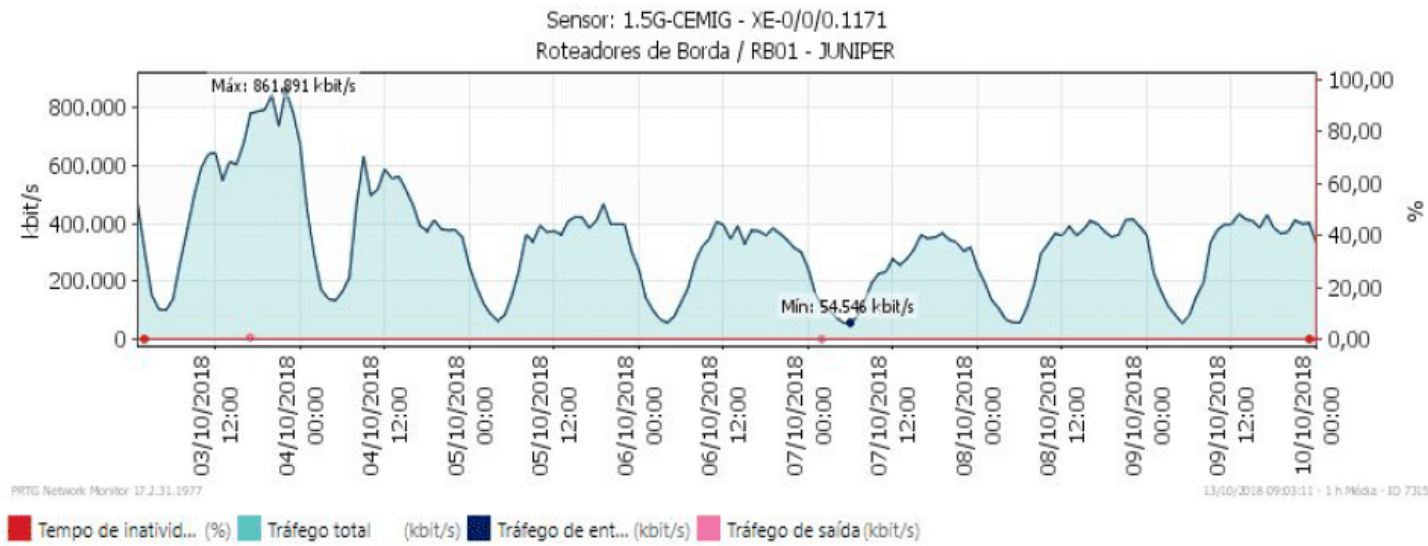

Source: Search data

Disponível em: https://www.nucleodoconhecimento.com.br/science-of-music/networks-of-smallinternet 
Operadora: 01

Capacidade: 4Gbps / Download Máximo no período: $2,8 \mathrm{Gbps}$

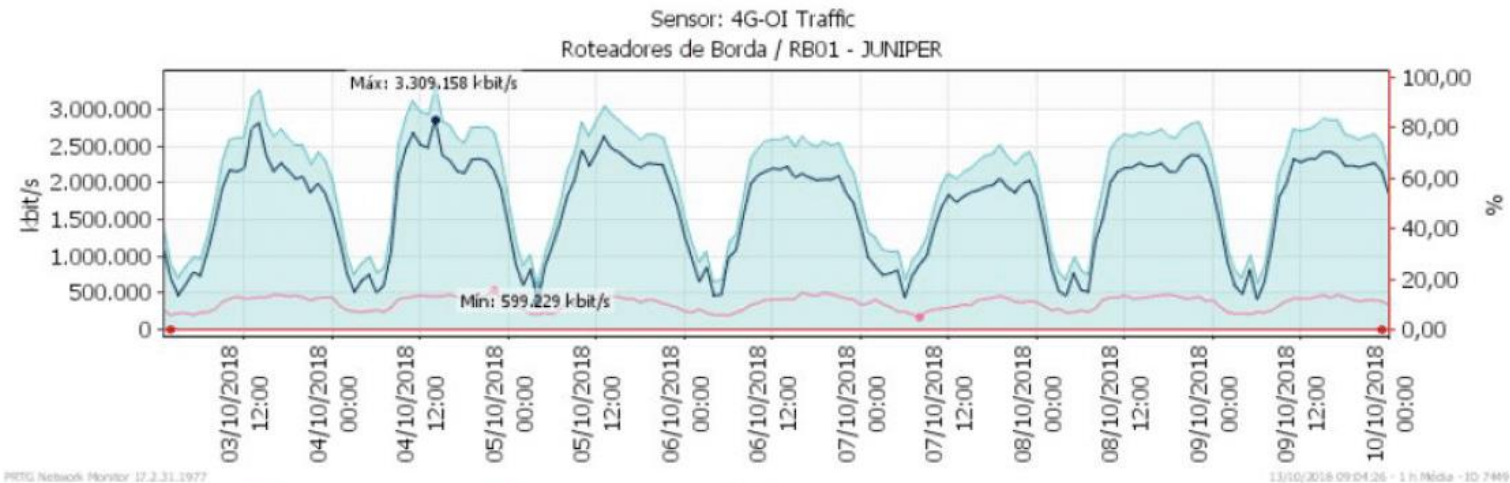

Tempo de inativid... (\%) \Tráfego total (kbit/s) Tráfego de ent... (kbit/s) W Tráfego de saída(kbit/s)

Figure 8 - Google CDN Traffic

Google - (11/10 a $13 / 10)$

Capacidade: 15 Gbps / Download Máximo no período: 660 Mbps

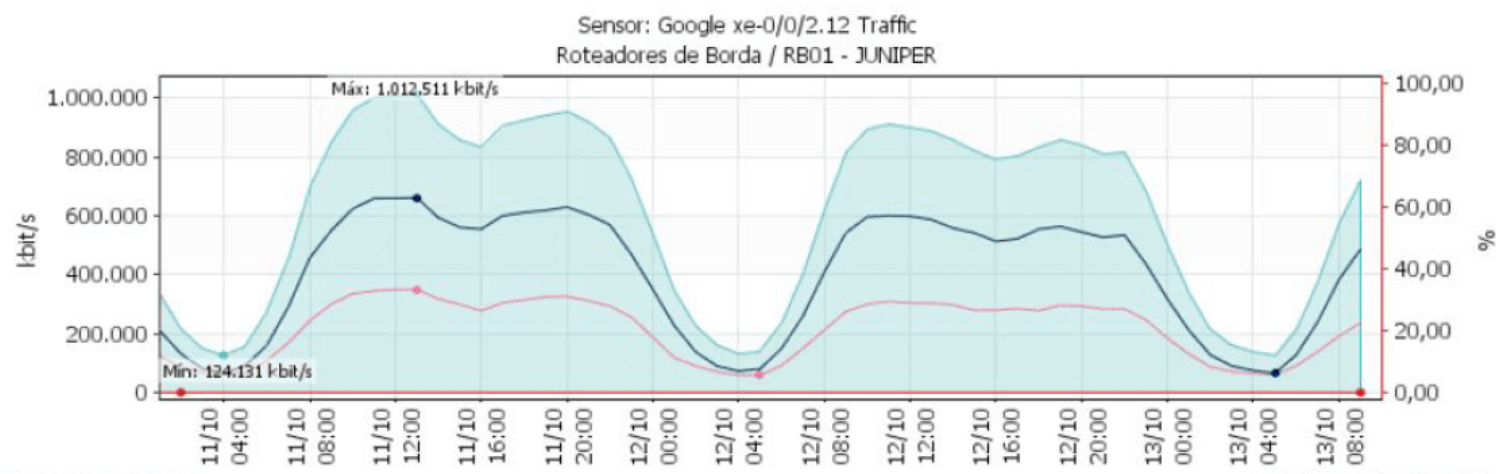

Tempo de inativid... (\%) [Tráfego total (kbit/s)

Tráfego de ent... (kbit/s) WTráfego de saída (kbit/s)

Source: Search data

\subsection{SUBSCRIBER TRAFFIC AFTER ACTIVATION OF CDNS FROM NETFLIX, FACEBOOK AND GOOGLE}

According to data from the latest survey (SANDVINE, 2018), in 2018, almost $58 \%$ of Internet downstream traffic is video. Netflix remains at the top of the internet's largest traffic applications with $19.10 \%$ (nineteen, ten percent) of all Internet traffic on the American continent. At peak times on fixed networks, this number can reach $40 \%$ on

$\mathrm{RC}: 39487$

Disponível em: https://www.nucleodoconhecimento.com.br/science-of-music/networks-of-smallinternet 
some carrier networks in the region. Youtube represents $7.53 \%$ (seven, fifty-three percent) and social networks, including Facebook, represent 5.1 (five, one percent) of all Internet traffic on the continent. Also, according to (CISCO, 2018) CDNs will carry $72 \%$ of Internet traffic by 2022, compared with 56\% in 2017.

Based on data from Sandvine and Cisco surveys and provider traffic evaluated, figure 9 shows that there was no need to increase the final capacity of the links. Figure 9 shows the total traffic of the two links of provider 18 (eighteen) months after the deployment of cdn netflix. The provider had 2,000 $(2,000)$ more clients over the initial date of activation of CDNs, that is, represents the total traffic of just over 10,000 (ten thousand) customers.

Even with the increase of more than 2000 customers and increased minimum speeds (more than 5 times), in the plans offered to customers by the provider, there was no need to increase the final capacity of the links. The maximum downstream speed in the period evaluated (April 2019) did not exceed the maximum downstream speed recorded when the initial CDN deployment. This shows the large use of CDNs in downstream traffic on the provider. In the perido the maximum downstream speed in the two links was 2.8 Gbps.

Figure 9 - Total traffic on the two links of the provider eighteen months after the activation of the CDNs

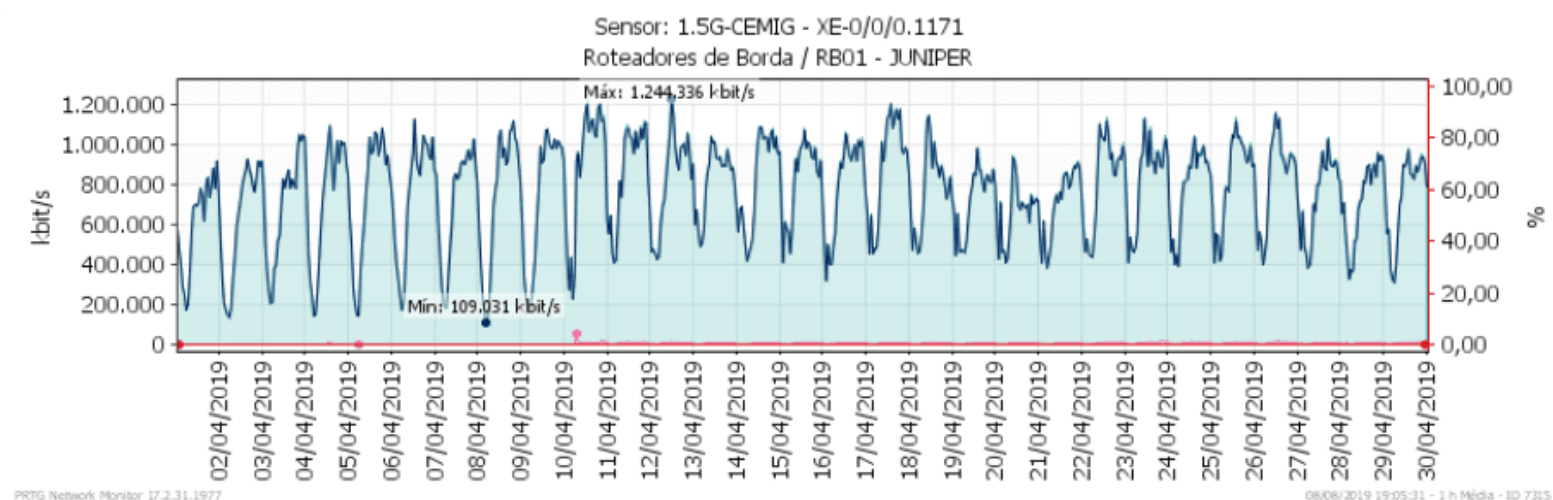

Tempo de inativid...(\%) — Tráfego total (kbit/s)

Source: Search data

Disponível em: https://www.nucleodoconhecimento.com.br/science-of-music/networks-of-smallinternet 


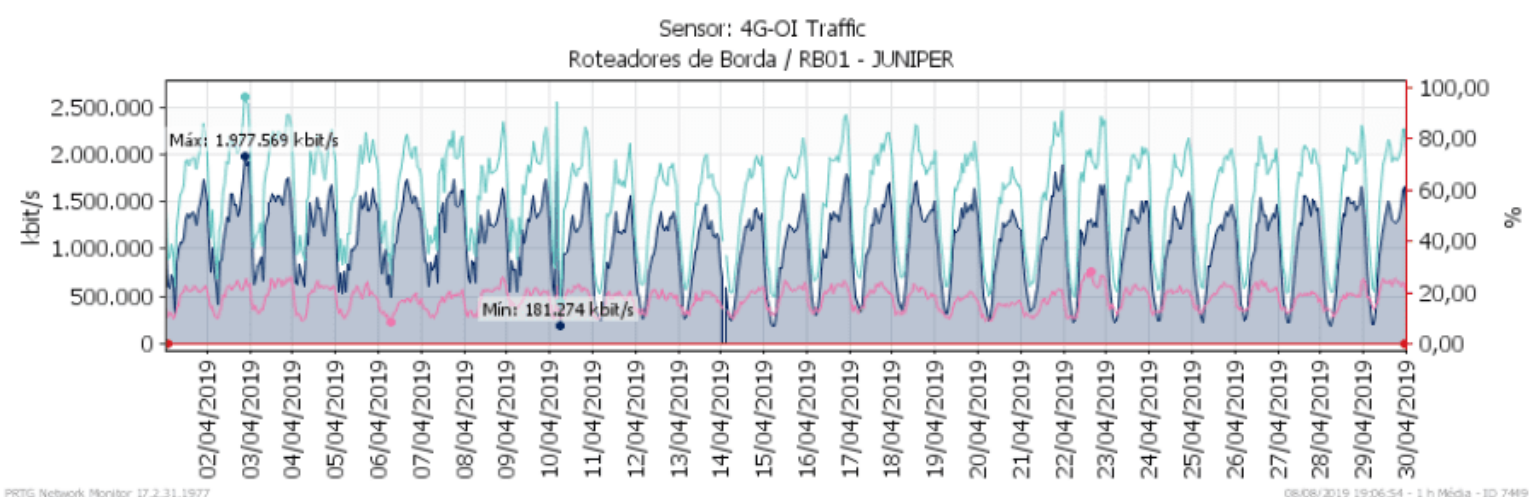

Tempo de inativid...(\%) Tráfego total (kbit/s)

Tráfego de en... (kbit/s) Tráfego de saí... (kbit/s)

Source: Search data

Figure 10, Figure 11 and Figure 12 are represented, respectively, the traffic of Netflix, Facebook and Google in April 2019.

Figure 10 - Netflix CDN Traffic

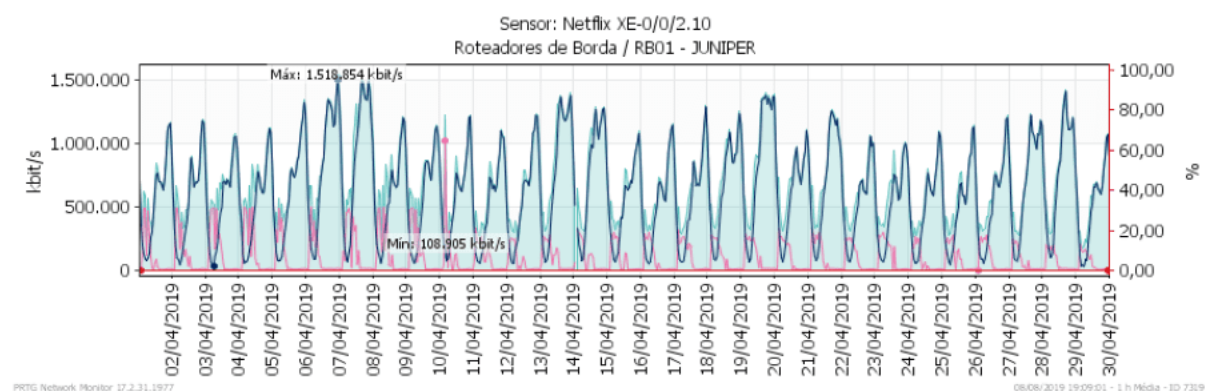

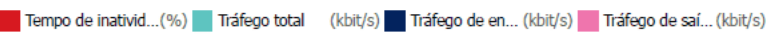

Source: Search data

Figure 11 - FACEBOOK CDN Traffic

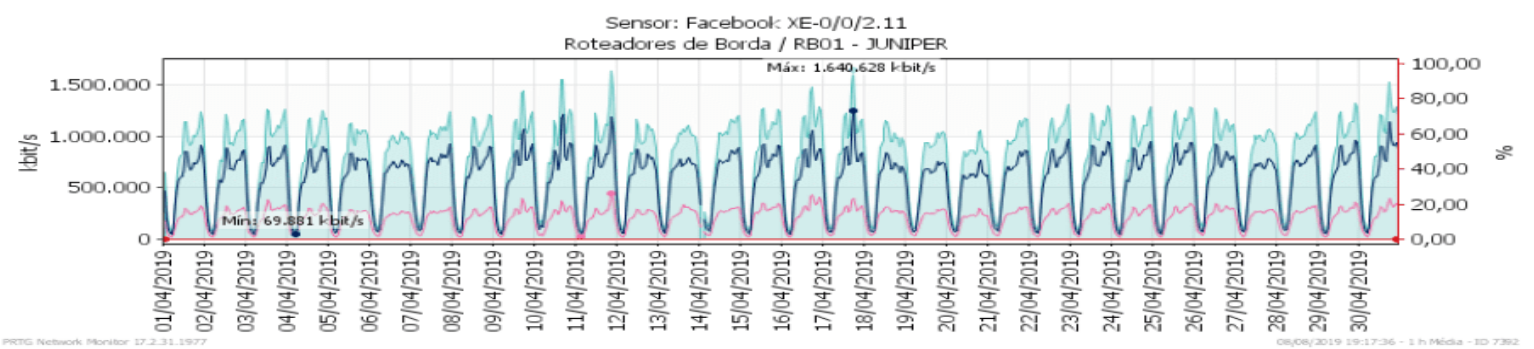

Tempo de inativid...(\%) \ Tráfego total (kbit/s) प Tráfego de en... (kbit/s) $\square$ Tráfego de saí... (kbit/s)

Source: Search data

RC: 39487

Disponível em: https://www.nucleodoconhecimento.com.br/science-of-music/networks-of-smallinternet 
Figure 10 - Google CDN Traffic

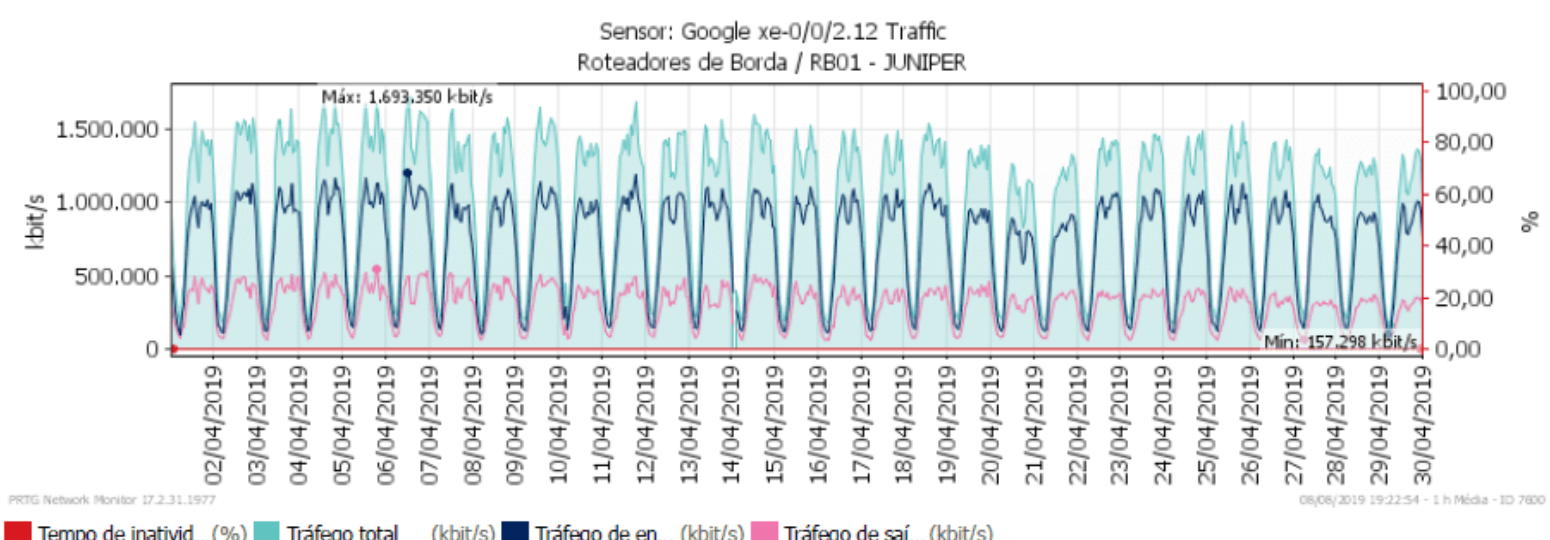

Source: Search data

Average traffic in the Netflix CDN period was $724.07 \mathrm{Mbps}$ for total traffic and 623.34 Mbps for downstream traffic, with a maximum value reaching $1.16 \mathrm{Gbps}$ in the night period between 8:00 p.m. and 11 p.m.

For the same period, the average traffic of the Facebook CDN was 788.97 Mbps for total traffic and 578.83 Mbps for downstream traffic, with maximum value reaching 912 Mbps in the night period between 8:00 p.m. and 10:00 p.m.

Average traffic in the Google CDN period was $1.0 \mathrm{Gbps}$ for total traffic and 710.55 Mbps for downstream traffic, with maximum value reaching 1.2 Gbps in the periods between 10:00 am to 3:00 pm and 18:00 to $11: 00 \mathrm{pm}$.

The average traffic of the two links was $2.33 \mathrm{Gbps}$ for total traffic and $1.84 \mathrm{Gbps}$ for downstream traffic, with a maximum value reaching $2.80 \mathrm{Gbps}$. These values represent all traffic generated by clients that are not directed to the three CDNs.

Thus, it can be deduced that the average total traffic generated by the provider's customers reaches $4.84 \mathrm{Gbps}$ (2.33 Gbps + 724.07 Mbps + 788.97 + $1 \mathrm{Gbps}$ ) for total traffic and 3.75 Gbps (1.84 Gbps + 623.34 Mbps + 578.83 Mbps + 710.55) for downstream traffic.

Disponível em: https://www.nucleodoconhecimento.com.br/science-of-music/networks-of-smallinternet 
Based on this data, it is inferred that traffic from Netflix, Facebook and Google CDNs account for close to $52 \%$ of the average total traffic generated by customers, with individual participation of $15 \%$ for Netflix, $16 \%$ for Facebook and $21 \%$ for Google (including youtube). These figures match NIC.br estimates, in which it establishes that services such as YouTube, Netflix, Facebook and Google generate up to $60 \%$ of residential user traffic in the country.

\section{FINAL CONSIDERATIONS}

It's no surprise that video streaming is the best type of internet app, associated with social networks. The video continues to drive downstream bandwid th usage.

As small ISPs are directly responsible for the care of the home market in Brazil, especially in regions not assisted by large operators. They need to understand the composition of traffic (not content) so that they can build a network capable of meeting consumer quality expectations, and ensuring a good user experience using solutions that increase the speed of delivery, such as CDN.

As a result of this work it is possible to have a reference for the dimensioning of internet backbone access links via IP port and the use of CDN in the ISP or PTT environment. The use of local CDNs in the ISP results in great savings in the hiring of links and great internet browsing experience by users.

The use of CDNs in small providers is highly relevant for the dissemination of quality Internet access, allowing the increase in internet access speed and the reduction of the values of the plans offered to customers, benefiting the population as a whole in its insertion into the Information Society.

\section{REFERENCES}

CASTELLS, Manoel. A sociedade em Rede. 8 ed. Rio de Janeiro: Paz e Terra, 1999. $639 p$, Volume 1. 
CISCO. Cisco Visual Networking Index: Forecast and Methodology, 2016-2021. 2017. Disponível em: <http://www.cisco.com/c/en/us/solutions/collateral/serviceprovider/visual-networking-index-vni/complete-white-paper-c11-481360.pdf>. Acesso em 07/07/2017.

CISCO. Cisco Visual Networking Index: Forecast and Methodology, 2017-2022. 2018. Disponível em: < https://www.cisco.com/c/en/us/solutions/collateral/serviceprovider/visual-networking-index-vni/white-paper-c11-741490.html >. Acesso em 07/02/2019.

COMITÊ GESTOR DA INTERNET NO BRASIL - CGI. Pesquisa sobre o setor de provimento de serviços de Internet no Brasil [livro eletrônico]: TIC Provedores $2014=$ Survey about the Internet service provider sector in Brazil: ICT Providers 2014 / [coordenação executiva e ditorial/executive and editorial coordination, Alexandre F. Barbosa; tradução para o inglês/ translation into English Prioridade Consultoria]. -- São Paulo: Comitê Gestor da Internet no Brasil, 2016. 987 Kb; PDF. Disponível em: $<$ http://cetic.br/media/docs/publicacoes/2/TIC_Provedores_2014_livro_eletronico.pdf >. Acesso em 10/07/2017.

KURBALIJA, Jovan. Uma introdução à governança da internet [livro eletrônico] / Jovan Kurbalija; [Zoran Marcetic -Marca \& Vladimir Veljasevic; tradução Carolina Carvalho]. -- São Paulo: Comitê Gestor da Internet no Brasil, 2016. Disponível em < https://www.cgi.br/media/docs/publicacoes/1/CadernoCGlbr_Uma_Introducao_a_Go vernanca_da_Internet.pdf>. Acesso em 10/07/2017.

NETO, Marques, H. T., Almeida, V. A. F., and Almeida, J. M. Pricing broadband internet adaptive services. 15th International Symposium on Modeling, Analysis, and Simulation of Computer and Telecommunication Systems, 2007. MASCOTS'07. Pages 158-165.

OTT SOURCE 2013. OTT BLOG. Disponível em: < http://ottsource.com/ott-blog/>. Acesso em 05/07/2017. 
OVUM. The Evolution of Big Video. Examining telco transformation video opportunities. $2016 . \quad$ Disponível em $<$ http://photos.prnasia.com/fileman/static_file/do_download?seq=1\&permalink=20160829/0861608784-a >. Acesso em 10/07/2017.

SANDVINE. The Global Internet Phenomena Reports, 2016. Disponivel em: https://www.sandvine.com/trends/global-internet-phenomena/. Acesso em 05/07/2017.

SANDVINE. The Global Internet Phenomena Reports, 2018. Disponivel em: https://www.sandvine.com/hubfs/downloads/phenomena/2018-phenomenareport.pdf. Acesso em 05/08/2019.

Submitted: August, 2019.

Approved: September, 2019. 